DOI: $10.7596 /$ taksad.v2i2.246

\title{
Investigating Self-Regulated Learning Habits of Distance Education Students
}

\author{
Ozkan KIRMIZI*
}

\begin{abstract}
This study aims at exploring self-regulated learning habits of distance education students. Self-regulation can be defined as a process where learners take the initiative, with or without the guidance of others, in identifying their own needs, formulating goals, exploring resources, focusing on appropriate learning strategies, and evaluating learning outcomes. This study investigates self-regulated learning in terms of goal setting, environment structuring, time management, help seeking, self-evaluation, and metacognition. In the case of distance education learners, self-regulation assumes more importance due to the fact that distance education learners are supposed to direct their own learning process themselves. In order to collect data, Online Self-Regulated Learning Scale (OSLQ) and Motivated Strategies for Learning Questionnaire (MSLQ) were used. These two scales were adapted according to the scope of the study. The number of participants is 75 . Results indicate that distance education learners must improve themselves in terms of their self-regulated learning habits.
\end{abstract}

Key words: self-regulation, self-regulated learning, distance education.

\footnotetext{
* Karabuk University.
} 


\section{Introduction}

The increasing trend in education today is to enable learners to be able to control their own learning processes. Chen (2002) observed that as a result of the rise of cognitivism in educational psychology learners are supposed to have more responsibility on their own learning. This led to a proliferation of research studies on self-regulated learning in educational research. As Perkins (1992) emphasized two decades ago, today learners are expected to be actively engaged in reorganizing and reconstructing their existing knowledge with new knowledge rather than being passive absorbers.

Self-regulation indicates initiation of action on the part of learner. It includes goal setting and regulating one's efforts to realize desired aims, self-monitoring (metacognition), time management, and management of physical and social environment (Zimmerman \& Risemberg, 1997).

\section{Self-regulated learning}

Knowles defines self-regulated learning as "a process in which individuals take the initiative, with or without the help of others, in diagnosing their learning needs, formulating goals, identifying human and material resources, choosing and implementing appropriate learning strategies, and evaluating learning outcomes" (1975, p. 18). This definition is highly comprehensive and indicates a complex learning process that makes high demands on students for choices (Boekaerts, 1997; Winne \& Perry, 2000). Paris and Paris (2001) stated that self-regulated learning "emphasizes autonomy and control by the individual who monitors, directs, and regulates actions toward goals of information acquisition, expanding expertise and self-improvement" (p. 89). To summarize, we can say that self-regulated learners are "metacognitively, motivationally, and behaviorally active participants in their own learning process" (Zimmerman, 1989a, p. 4).

According to Barnard, Paton and Lan (2008), "the importance of self-regulation in improving learning outcomes in online and face-to-face formats cannot be overstated" (p.1). Research indicates that students who have higher level of self-regulation skills perform better than those students who have lower levels of self-regulation skills (Schunk \& Zimmerman, 1998; Zimmerman \& Schunk, 2001). Therefore, self-regulated learning can be viewed as an essential mainstay for the learning process of individuals both in online and face-to-face education settings.

Self-regularatory behaviors include goal setting, environment structuring, time management, help seeking, self-evaluation, and metacognition. Some of these self-regulatory behaviors, like goal setting, may be more explicit, while others, like environment structuring are more implicit (Barnard, Paton and Lan, 2008). However, they are all equally important behaviors on the achievement and performance of learners (Barnard, Paton and Lan, 2008). 


\section{Goal Orientation}

Goal orientation or goal setting is an important component of self-regulatory learning. Goal orientation is defined as learners' general goals or orientation toward a course (Pintrich, Smith, Garcia, and McKeachie, 1991). Research indicates that goal orientation is significant in the completion of courses. Beatty-Guenter (2001), for example, identified goal orientation as a significant attribute of those learners who completed their courses. Thompson (1998) stated that setting clear goals is an important element of academic performance. In addition, a number of research studies found that effective goal setting by distance learners contributes to performance (Curry, Haderlie, and Ku, 1999; Schrum and Hong, 2002).

\section{Physical and Social Environment Management}

Regulating the physical and social study environments includes effective environment management and help seeking (Zimmerman \& Risemberg, 1997). In literature, high achievement is reported to involve a greater use of environment management skills (Zimmerman \& Martinez-Pons, 1986). As Lynch and Dembo (2004, p. 4) also point out that "since distance education students do not study in a structured and controlled classroom context, they must be able to structure their own physical learning environment, whether at home or elsewhere."

\section{Time Management}

Another feature of self-regulated learning is time management. Time management includes "scheduling, planning, and managing one's study time." (Chen, 2002, p. 14). Literature indicates that training in time planning and management help students to use their study time more effectively (Zimmerman, Greenberg, \& Weinstein, 1994). It is stated that interacting in a Web-based course can require two to three times the amount of time investment than in a face-to-face course (Palloff and Pratt,1999). Self-regulated learners know how to manage their time and they can order their learning activities. Quite recently, Nonis et al. (2006) found that organizational and time-management strategies are strong predictors of academic achievement.

\section{Help seeking}

Another important distinguishing characteristic of self-regulated learners is the ability to pursue academic help in an "adaptive manner" (Lynch \& Dembo, 2004, p.4) to promote learning. The importance of help seeking in distance education has been reported by several authors (Hara and Kling, 2000; Holmberg, 1995; Wang \& Newlin, 2002). In addition, Karabenick (1998) found help seeking to be a valuable strategy for higher achievement. Selfregulated distance education students are supposed to be able to seek assistance from others due to the fact that distance education students are isolated from classmates and instructors. In 
this case, they need to use technology and other means effectively in order to lessen the social distance.

\section{Self-evaluation}

Self-evaluation is one of the crucial phases in which individuals evaluate their personal effectiveness in relation to a specific learning tasks. Self-evaluation is essential in guiding the learning process on the part of distance education students on account of the fact that they are isolated from other classmates and have to direct their own learning themselves. Therefore, distance education students are expected to have sound self-evaluation skills in order to successfully continue their learning.

\section{Metacognitive Self-regulation}

A fundamental component of self-regulated learning is metacognition. As is known, metacognition includes awareness, knowledge, and control of cognition. Metacognitive selfregularoty learning is composed of activities like planning, monitoring, and regulation. (Pintrich et al, 1991). Planning embodies goal setting and task analysis. Effective selfregulated learners can set relevant goals and then monitor the effectiveness of their learning methods or strategies and respond to their evaluations (Zimmerman, 1989). Therefore, selfmonitoring can be viewed as an essential factor in improving learning. In addition, learners with high metacognitive awareness can concentrate on their work more effectively and eliminate inadequate learning strategies.

\section{Aims of the study}

The study was carried out in order to get a general picture of self-regulation skills of distance education students. In order to do this, the following research questions were formulated:

\section{Research questions}

1. What are the self-perceptions of distance education students in terms of goal setting?

2. What are the self-perceptions of distance education students in terms of environment structuring?

3. What are the self-perceptions of distance education students in terms of time management?

4. What are the self-perceptions of distance education students in terms of help seeking?

5. What are the self-perceptions of distance education students in terms of selfevaluation?

6. What are the self-perceptions of distance education students in terms of metacognitive strategies? 
7. Are there statistical differences between male and female students in terms of selfregulation?

8. Are there statistical differences among first, second and third grade students' in terms of self-regulation?

\section{Method}

The study is a descriptive study. It aims at getting an understanding of the status of distance education students in terms of 6 dimensions of self-regulated learning.

\section{Participants}

The study was carried out with 75 distance education students. They are all enrolled at English Language and Literature department of Karabük University. The number of female participants is 52 and male students 23 . The number of first grade students is 18 , second grade students 23 , and third grade students 34 . The numbers about participants are given in table 1 .

Table 1. participants by grade and gender

\begin{tabular}{llll}
\hline Participants & Male & Female & Total \\
\hline $1^{\text {st }}$ grade & 3 & 15 & 18 \\
$2^{\text {nd }}$ grade & 6 & 17 & 23 \\
$3^{\text {rd }}$ grade & 14 & 20 & 34 \\
Total & 23 & 52 & 75 \\
\hline
\end{tabular}

\section{The Instrument}

The research instrument was developed by extensive analysis of the literature. Studies on self-regulation were analyzed and the research tool was developed. Five of the dimensions of self-regulation were adapted from Online Self-Regulated Learning Scale (OSLQ). OSLQ was developed by Barnard et al. (2009). It consists of six factors and 24 items in total. The reliability analysis of the instrument is given in the table below. It is clear from the table that the Cronbach's Alpha level for all dimensions is above ,50. Therefore, we can say that the instrument is reliable. In order to measure meta-cognition, Motivated Strategies for Learning Questionnaire (MSLQ) was used. Some of the items in this tool were adapted and some of them were changed according to the aims of the study. MSLQ was developed by Pintrich and his colleagues in the 1990s at the University of Michigan (Pintrich et al. 1994). 
Table 2. Reliability analysis

\begin{tabular}{lll}
\hline & $\alpha$ & Number of items \\
\hline Goal setting &, 841 & 5 \\
Environment structuring &, 766 & 4 \\
Time management &, 744 & 5 \\
Time seeking &, 744 & 4 \\
Self-evaluation &, 717 & 4 \\
Meta-cognition &, 896 & 9 \\
\hline
\end{tabular}

\section{Data analysis}

The data have been analyzed by using the package program SPSS. In the first place, descriptive statistics for the six dimensions were calculated in order to see the general picture. Each dimension is given in separate tables with consensus analysis and the result. Consensus analysis was carried out by using the top percentages. The type was decided upon based on the top percentages. As a next step, the data were subjected to further statistical analysis (ttest) in order to see whether there are differences between male and female students in terms of self-regulation. Finally, ANOVA was conducted in order to compare first, second and third grade students in terms of the six dimensions of self-regulation.

\section{Results}

Research question 1: What are the self-perceptions of distance education students in terms of goal setting?

Table 3. Distance education students' self-perceptions about goal setting

\begin{tabular}{lll}
\hline GOAL SETTING & Percent & Type \\
\hline I set standards for my assignments in online courses. & 45,3 & undecided \\
I set short-term (daily or weekly) goals as well as long-term goals & 37,3 & Agree \\
(monthly or for the semester). & & \\
I keep a high standard for my learning in my online courses. & 40 & Undecided \\
I set goals to help me manage study time for my online courses. & 52 & Agree \\
I achieve goals I set for myself. & 49,3 & Agree \\
\hline
\end{tabular}


Item 1 in table 3 indicates that distance education students are undecided about setting standarts for their online courses. The second item was agreed by 37,3\% of the participants. This indicates that they seet goals. However, the total percentage is rather low. For the third item, we can see that distance education students are undecided about keeping high standards about their online courses. This is in line with the first item. The next two items are agreed by the participants with high percentages ( $\%=52, \% 49,3$, respectively). It is possible to state that distance education students can set goals to manage their study time and they can achieve the goals they have set.

Research question 2: What are the self-perceptions of distance education students in terms of environment structuring?

Table 4. Distance education students' self-perceptions about environment structuring

\begin{tabular}{lll}
\hline ENVIRONMENT STRUCTURING & Percent & Type \\
\hline 1. I choose the location where I study to avoid too much distraction. & 52 & Agree \\
2. I find a comfortable place to study. & 48 & Agree \\
3. I know where I can study most efficiently for online courses. & 57,3 & Agree \\
4. I choose a time with few distractions for studying for my online courses. & 40 & Agree \\
\hline
\end{tabular}

From table 4, we can understand that distance education students can manage their study environment relatively effectively. All of the items were agreed by the participants with fairly high percentages.

Research question 3: What are the self-perceptions of distance education students in terms of time management?

Table 5. Distance education students' self-perceptions about time management

\begin{tabular}{lll}
\hline TIME MANAGEMENT & Percent & Type \\
\hline $\begin{array}{l}\text { 1. I allocate extra studying time for my online courses because I know it is time- } \\
\text { demanding. }\end{array}$ & Agree \\
2. I try to schedule the same time every day or every week to study for my & 40 & Agree \\
$\quad \begin{array}{l}\text { online courses, and I observe the schedule. } \\
\text { 3. Although we don't have to attend daily classes, I still try to distribute my }\end{array}$ & 45,3 & Agree \\
$\quad \begin{array}{l}\text { studying time evenly across days. } \\
\text { 4. I prepare my questions before joining in the chat room and discussion. }\end{array}$ & 40 & Disagree \\
5. I organize my time to complete course requirements in a timely manner. & 38,6 & Disagree \\
\hline
\end{tabular}

In terms of time management, which is one of the most important skills for distance education students, the first three items were agreed by the participants. We can understand 
that distance education students can allocate extra time for their study and schedule their study time effectively. However, the last two items are disagreed by the participants. It can be said that distance education students do not come to online courses with questions in their minds about course content. Moreover, they have problems in completing course requirements in a timely manner.

Research question 4: What are the self-perceptions of distance education students in terms of help seeking?

Table 6. Distance education students' self-perceptions about help seeking

\begin{tabular}{lll}
\hline HELP SEEKING & Percent & Type \\
\hline $\begin{array}{l}\text { 1. I find someone who is knowledgeable in course content so that I can } \\
\text { consult with him or her when I need help. }\end{array}$ & Agree \\
$\begin{array}{l}\text { 2. I share my problems with my classmates online so we know what we } \\
\text { are struggling with and how to solve our problems. }\end{array}$ & Agree \\
$\begin{array}{l}\text { 3. I am persistent in getting help from the instructor through e-mail. } \\
\text { S }\end{array}$ & 46,6 & Agree \\
\hline
\end{tabular}

When it comes to the next dimension of self-regulation, help seeking, we can see in table 6 that three of the items are agreed by distance education students. Therefore, we can say that distance education students do not have problems in terms of asking for help when needed.

Research question 5: What are the self-perceptions of distance education students in terms of self-evaluation?

Table 7. Distance education students' self-perceptions about self-evaluation

\begin{tabular}{lll}
\hline SELF-EVALUATION & Percent & Type \\
\hline $\begin{array}{l}\text { 1. I summarize my learning in online courses to examine my understanding of } \\
\text { what I have learned. }\end{array}$ & 42,6 & Agree \\
2. I ask myself a lot of questions about the course material when studying for an & 41,3 & Undecided \\
online course. & Agree \\
$\begin{array}{l}\text { 3. I communicate with my classmates to find out how I am doing in my online } \\
\text { classes. }\end{array}$ & 42,6 & Agree \\
$\begin{array}{l}\text { 4. I communicate with my classmates to find out what I am learning that is } \\
\text { different from what they are learning. }\end{array}$ &
\end{tabular}

In table 7 , it is clear that the three items related to self-evaluation are agreed by the participants. This indicates that distance education students can perform self-evaluation skills. However, the second item was categorized as undecided. It is related to askings questions. Distance education students do not seem to inquire into the course content they are working on effectively. 
Research question 6: What are the self-perceptions of distance education students in terms of metacognitive strategies?

Table 8. Distance education students' self-perceptions about metacognition

\begin{tabular}{lll}
\hline METACOGNITION & Percent & Type \\
\hline $\begin{array}{l}\text { 1. I am responsible for my own education; what I learn is ultimately my } \\
\text { responsibility. }\end{array}$ & 57,3 & Agree \\
$\begin{array}{l}\text { 2. During class time, I'm highly concentrated on what is being done. } \\
\text { 3. If course readings are difficult to understand, I change the way I study. }\end{array}$ & 46,6 & Agree \\
$\begin{array}{l}\text { 4. I ask myself questions to make sure that I understand the course } \\
\text { materials. }\end{array}$ & 45,3 & Agree \\
$\begin{array}{l}\text { 5. I try to change the way I study in order to fit the course requirements } \\
\text { 6. I try to think through a topic and decide what I am supposed to learn } \\
\text { from it rather than just reading it over when studying. }\end{array}$ & 46,6 & Agree \\
$\begin{array}{l}\text { 7. When I study for this class, I set goals for myself in order to direct my } \\
\text { activities in each study period. }\end{array}$ & 42,6 & Undecided \\
8. I regulate and adjust my behavior to complete course requirements. & 46,6 & Agree \\
9. I understand the main ideas and important issues of readings without \\
$\begin{array}{l}\text { guidance from the instructor. } \\
48\end{array}$
\end{tabular}

The last dimension of self-regulation is metacognition. The results in table 8 show that the first five items are agreed by the participants. We can say that distance education students are aware of their responsibities in their own learning. There are only two items which are ranked as undecided by the participants. We can understand that distance education students do not seem to think through a topic and try to single out major points in the subject matter. In the second place, we can say that distance education students do not seem to be setting goals efficiently to direct their own learning.

Table 9. The six dimensions of self-regulation

\begin{tabular}{lcccccc}
\hline Self-regulation & \multicolumn{2}{c}{ Low } & \multicolumn{2}{c}{ Moderate } & \multicolumn{2}{c}{ High } \\
& $f$ & $\%$ & $f$ & $\%$ & $f$ & $\%$ \\
\cline { 2 - 7 } Goal setting & 4 & 5,3 & 31 & 40,8 & 41 & 53,9 \\
Environment structuring & 8 & 10,5 & 53 & 69,7 & 14 & 18,4 \\
Time management & 5 & 6,7 & 39 & 52 & 31 & 41,3 \\
Help seeking & 7 & 9,3 & 43 & 57,3 & 25 & 33,3 \\
Self-evaluation & 2 & 2,7 & 64 & 85,3 & 9 & 12 \\
Metacognition & 3 & 4 & 28 & 37,3 & 44 & 58,7 \\
\hline
\end{tabular}


We can understand from the table above that distance education students have a high level of goal setting skills. For environment structuring, the results indicate a moderate level of mean scores. We can say that distance education students can perform better in terms of environment structuring. Another important dimension of self-regulation, time management skills, is found to be on a moderate level on the part of distance education students. In the same way, help seeking skills were also found to be on a moderate level. For self-evaluation, which is one of the most important dimensions of self-regulation, distance education students perceive themselves moderately successful. Finally, when it comes to metacognition the results indicate that distance education students view themselves relatively successful in their meta-cognitive abilities.

Research question 7: Are there statistical differences between male and female students in terms of self-regulation?

Table 10. t-test results for gender and self-regulation

\begin{tabular}{lccccc}
\hline Self-regulation & \multicolumn{2}{c}{ Male } & \multicolumn{2}{c}{ Female } & \\
& M & SD & M & SD & t-test \\
\cline { 2 - 6 } Goal setting & 15,08 & 4,198 & 16,80 & 4,196 &, 106 \\
Environment structuring & 13,26 & 4,125 & 13,32 & 3,104 &, 946 \\
Time management & 14,17 & 4,951 & 15,86 & 3,673 &, 151 \\
Help seeking & 12,08 & 3,604 & 13,00 & 3,772 &, 331 \\
Self-evaluation & 12,34 & 3,524 & 13,11 & 2,961 &, 368 \\
Metacognition & 29,91 & 7,815 & 30,26 & 6,897 &, 851 \\
\hline $\mathrm{P}(0,05)$ & & & & &
\end{tabular}

An independent-samples t-test was conducted to compare male and female students in relation to the six dimensions of self-regulation. The results suggest that there are no statistical differences between male and female students in terms of self-regulation. Yet, we can understand from table 10 that the mean scores of female students are slightly higher than that of male students.

Research question 8: Are there statistical differences among first, second and third grade students' in terms of self-regulation? 
Table 11. Year and self-regulation (ANOVA)

\begin{tabular}{llllll}
\hline Variables & Grade & N & M & Sd & Sig. \\
\hline Goal setting & $1^{\text {st }}$ grade & 18 & 15,88 & 4,873 &, 294 \\
& $2^{\text {nd }}$ grade & 23 & 17,43 & 4,439 & \\
Environment structuring & $3^{\text {rd }}$ grade & 34 & 15,70 & 3,697 & \\
& $1^{\text {st }}$ grade & 18 & 13,27 & 3,561 &, 657 \\
& $2^{\text {nd }}$ grade & 23 & 13,82 & 3,325 & \\
Time management & $3^{\text {rd }}$ grade & 34 & 12,97 & 3,468 & \\
\multirow{4}{*}{ Help seeking } & $1^{\text {st }}$ grade & 18 & 15,33 & 4,000 &, 981 \\
& $2^{\text {nd }}$ grade & 23 & 15,21 & 4,100 & \\
Self-evaluation & $3^{\text {rd }}$ grade & 34 & 15,44 & 4,370 & \\
\multirow{4}{*}{ Metacognition } & $1^{\text {st }}$ grade & 18 & 12,88 & 3,027 &, 333 \\
& $2^{\text {nd }}$ grade & 23 & 11,78 & 3,741 & \\
& $3^{\text {rd }}$ grade & 34 & 13,26 & 4,009 & \\
& $1^{\text {st }}$ grade & 18 & 13,38 & 2,523 &, 632 \\
& $2^{\text {nd }}$ grade & 23 & 12,43 & 3,940 & \\
& $3^{\text {rd }}$ grade & 34 & 12,91 & 2,864 & \\
& $1^{\text {st }}$ grade & 18 & 30,16 & 7,437 &, 992 \\
& $2^{\text {nd }}$ grade & 23 & 30,30 & 6,567 & \\
& $3^{\text {rd }}$ grade & 34 & 30,05 & 7,551 & \\
\hline
\end{tabular}

In order to understand whether there are statistical differences among first, second and third grade students, ANOVA was applied. The three groups were compared in relation to their self-regulation skills in six dimensions. As table 11 indicates, there are no statistical differences among students at different grades. Therefore, we can rely on the general findings presented above in understanding the self-regulation skills of distance education students.

\section{Conclusion}

The present study was a descriptive study that attempted to document the selfregulated learning habits of distance education students. Self-regulation assumes particular significance on the part of distance education students due to the fact that distance education students are on their own to lead their own learning process. Therefore, they are supposed to have the necessary skills to direct their own learning process.

This study analyzed self-regulated learning habits of distance education students in relation to six dimensions of self-regulation. These are goal setting, environment structuring, time management, help seeking, self-evaluation, and metacognition. The study found that distance education students view themselves highly successful in goal setting and metacognition. These two dimensions are particularly important for distance education students on account of the fact that they are supposed to direct their own learning process themselves. In the second place, distance education students rated themselves moderately successful in 
environment structuring, help seeking, and self-evaluation. More specific findings of the study can be summarized as follows:

- $\quad$ Distance education students can set goals for themselves and they believe that they can attain the goals they have set for themselves.

- Distance education students can manage environmental factors to their satisfaction.

- Distance education students can manage their time. However, they may sometimes fail to do their final preparations for the lessons and they may have problems in completing course requirements in a timely manner.

- $\quad$ Distance education students are willing to seek help when needed.

- $\quad$ Distance education students can summarize their own learning but they do not seem to ask critical questions when working on course content. Moreover, they communicate with their classmates in order to guide their own learning.

- In terms of metacognition, it can be said that distance education students can direct their own learning. They can identify important points in the course materials as they are reading them. Depending on the findings, we can comfortably say that distance education students are well aware of their responsibilities.

As a second part of the study, self-regulation skills of distance education students were compared in relation to gender and status of students. The results indicated that there are no significant differences between male and female participants. In addition, there are no statistical differences among first, second and third grade students in terms of their selfregulation skills. 


\section{References}

Barnard, Paton and Lan, (2008). Online Self-Regulatory Learning Behaviors as a Mediator in the Relationship between Online Course Perceptions with Achievement, International Review of Research in Open and Distance Learning Volume 9, Number 2.

Bandura, A. (1986). Social Foundations of Thought and Action, Prentice-Hall, Englewood Cliffs, NJ.

Beatty-Guenter, P. (2001). Distance education: does access override success? Paper presented to the Canadian Institutional Research and Planning Association 2001conference, Victoria, British Columbia.

Boekaerts, M. (1999). Self-regulated learning: Where we are today. International Journal of Educational Research, 31(6), 445-457.

Chen, C. (2002). Self-regulated Learning Strategies and Achievement in an Introduction to Information Systems Course, Information Technology, Learning, and Performance Journal, Vol. 20, No. 1,

Curry, J., Haderlie, S., and Ku, T. (1999). Specified learning goals and their effect on learners' representations of a hypertext reading environment. International Journal of Instructional Media 26(1), 43 - 51.

Hara, N., and Kling, R. (2003). Students' distress with a web-based distance education course. Turkish Online Journal of Distance Education-TOJDE 4(2)

Holmberg, B. (1995). Theory and practice of distance education. London: Routledge.

Knowles, M. (1975). Self-directed learning: A guide for learners and teachers. New York: Association Press.

Lynch, R. \& Dembo, M. (2004). The Relationship Between Self-Regulation and Online

Learning in a Blended Learning Context, International Review of Research in Open and Distance Learning, 8/4

Nonis, S. A., Philhours, M. J., \& Hudson, G. I. (2006). Where does the time go? A diary approach to business and marketing students' time use. Journal of Marketing Education, 28, 121-134.

Palloff, R. M., and Pratt, K. (1999). Building learning communities in cyberspace: effective strategies for the online classroom. San Francisco: Jossey-Bass.

Paris, S. G., \& Paris, A. H. (2001). Classroom applications of research on self-regulated learning. Educational Psychologist, 36(2), 89-101.

Perkins, D. N. (1992). Technology meets constructivism: Do they make a marriage? . In T. M. Duffy \& D. H. Jonassen (Eds.), Constructivism and the technology of instruction: A conversation (pp. 45-55). Hillsdale, NJ: Lawrence Erlbaum Associates 
Pintrich, P. R., Smith, D. A. F., Garcia, T., and McKeachie, W. J. (1991). A manual for the use of the motivated strategies for learning questionnaire (MSLQ). 91-B-004. Ann Arbor: The Regents of the University of Michigan.

Pintrich, P. R., D. A. F. Smith, T. Garcia, and L. Mackeachie. 1994. A manual for the use of the motivated strategies for learning questionnaire (MSQL). Ann Arbor: University of Michigan.

Schunk, D. H., \& Zimmerman, B. J. (1998). Self-regulated learning: From teaching to selfreflective practice. New York: London.

Schrum, L., and Hong, S. (2002). Dimensions and strategies for online success: Voices from experienced educators. Journal of Asynchronous Learning Networks 6(1).

Thompson, M. M. (1998). Distance learners in higher education. In C. C. Gibson (Ed.), Distance learners in higher education: institutional responses for quality outcomes (pp. 924). Madison, Wisconsin: Atwood Publishing.

Wang, A. Y., \& Newlin, M. H. (2002). Predictors of Web-Student Performance: the role of self- efficacy and reasons for taking an on-line class. Computers in Human Behavior 18 (2), $151-163$.

Winne, P. H., \& Perry, N. E. (2000). Measuring self-regulated learning. In P. R. Pintrich, M. Boekaerts, \& M. Zeidner (Eds.), Handbook of self-regulation (pp. 531-566). San Diego, CA: Academic Press.

Zimmerman, B. J., \& Martinez-Pons, M. (1986). Development of a structured interview for assessing student use of self-regulated learning strategies. American Educational Research Journal, 23(4), 614- 628.

Zimmerman, B. J. (1989a). Models of self-regulated learning and academic achievement. In B. J. Zimmerman \& D. H. Schunk (Eds.), Self-regulated learning and academic achievement: Theory, research, and practice (pp. 1-25). New York: Springer-Verlag.

Zimmerman, B. J. (1989b). A social cognitive view of self-regulated learning. Journal of Educational Psychology, 81, 329-339.

Zimmerman, B. J., Greenberg, D., \& Weinstein, C. E. (1994). Self-regulating academic study time: A strategy approach. In D. H. Schunk \& B. J. Zimmerman (Eds.), Self-regulation of learning and performance: Issues and educational applications (pp. 181-199). Hillsdale, NJ: Lawrence Erlbaum Associates.

Zimmerman, B. J., \& Risemberg R. (1997). Selfregulatory dimensions of academic learning and motivation. In G. D. Phye (Ed.), Handbook of academic learning: Construction of knowledge (pp.105-125). San Diego, CA: Academic Press.

Zimmerman, B. J., \& Schunk, D. H. (2001). Self-regulated learning and academic achievement: Theoretical perspectives (2nd ed.). Mahwah, NJ.: Lawrence Erlbaum Associates 